Годищњак Филозофског̄ факулиеиейа у Новом Саду, Къиг̄a ХХХVIII (2013)

Annual Review of the Faculty of Philosophy, Novi Sad, Volume XXXVIII (2013)

Слободан Бјелица

Filozofski fakultet Универзитета у Новом Саду
УДК 325.85(497.113)“19““

Оригинални научни рад

\title{
ДВЕ КОНЦЕПЦИЈЕ ПОЛОЖАЈА ВОЈВОДИНЕ ТОКОМ УСТАВНЕ РЕФОРМЕ 60-ИХ ГОДИНА ХХ ВЕКА*
}

Почетком шездесетих година двадесетог века у југословенској политичкој јавности учестале су дискусије око предстојеће уставне реформе. У погледу будућег положаја Аутономне покрајине Војводине, сукобиле су се две концепције. Прва, коју је половином октобра 1961. године у београдској Борби, у четири наставка, објавио Милош Минић под насловом Прилог̄ дискусији о новом устиаву залагала се за хомогенију структуру Републике Србије. Према Минићевим идејама, иза којих је вероватно стајало тадашње републичко руководство, поред постојеће АП Војводине, односно Аутономне Косовско-метохијске области, предвиђено је формирање још неколико области на простору тзв. „Уже Србије“. Претходно је Минић опширно анализирао принципе политичког уређења са теоријског гледишта, историјски развој односа између републике и аутономних јединица и тада актуелно питање срезова. Са друге стране, стручњаци Завода за јавну управу АП Војводине, своје мишљење о предстојећим уставним променама предочили су још у пролеће (мај-јун) 1961. године, у виду неколико обимних списа. Реч се о реферату др Будимира Дамјанова и Миливоја Ковачевића под насловом Ауйономна йокрајина Војводина (иоложај и йрава), Информацији о неким

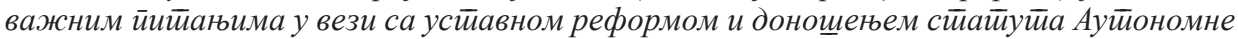
йокрајине Војводине, Коменйарима о йройисима савезног̄ и рейубличког̄ устиава који рег̄улищу ирравни йоложај АП Војводине, те још неким елаборатима.

Кључне речи: Аутономија, Војводина, Србија, Устав

Почетак шездесетих година XX века у Југославији је између осталог обележио и сукоб око аутономије Војводине између покрајинског и републичког руководства, а чији је повод било обнародовање уставне концепције истакнутог републичког функционера Милоша Минића. (Бјелица, 2011:19) Минићев Прилог̄ дискусији о новом устиаву (у скраћеном издању у складу са расположивим просторим у дневним новинама, а можда и политичким потребама) објављен је половином октобра 1961. године у Борби, у четири наставка. (Кончар и Боаров, 2011: 275-283) Сам аутор је свој допринос правдао потребом да изнесе своје мишљење у склопу текућих припрема уставних нацрта. На самом почетку Милош Минић је опширно анализирао маркси-

* sbjelica@EUnet.rs, 177002 Војвођански простор у контексту европске историје 
стичко-лењинистичка теоријска гледишта о принципима политичког уређења, између осталог и о аутономији и централизму. Други део Прилог̄a бави се југословенским искуством федерализма, са посебним освртом на односе савезне државе и њених федералних јединица. Трећи наставак у потпуности је посвећен развоју срезова, док је последњи део Минићевог списа, по његовим речима „веома кратак извод из опширније анализе извесних основних политичких и правних питања развоја аутономних јединица“. (Минић, 1961: 4)

Приказујући развој аутономних јединица од момента када су настале, „у намери да обезбеди да се схвати суштина развоја у одређеним фазама и проблеми даљег развоја““ Минић је подсетио на след догађаја који су довели до формирања аутономних јединица. Овде ћемо навести само оне везане за Војводину: захтев највишег представничког тела становништва Војводине - Главног народноослободилачког одбора Војводине да се Војводина присаједини федералној јединици Србији као Аутономна Покрајина, одговарајуће одлуке о прикључењу федералној Србији са политичко-правним статусом аутономне покрајине донете од стране највиших представничких органа Војводине као и од стране Антифашистичке скупштине Народног ослобођења Србије, односно Народне скупштине Србије; изјава делегације Главног НОО Војводине на заседању Антифашистичке скупштине Народног ослобођења Србије од 7. априла 1945. године; Резолуција Антифашистичке скупштине Народног ослобођења Србије од 8. априла 1945. године; Одлука Покрајинске Народноослободилачке скупштине Војводине од 31. јула 1945. године, те закон о установљењу и устројству Аутономије Покрајине Војводине и Председништва Народне скупштине Србије од 1. септембра 1945. године. Из свега тога Минић је извео закључак да је АПВ творевина становништва Војводине, које је преко својих највиших демократских представничких тела „изразило и формулисало своју вољу и своје жеље, и највишег представничког тела федералне јединице, тј. Народне Републике Србије које је на основи сопствених суверених права прихватило жеље становништва Покрајине“, те да, према томе, „имамо пред собом ванредно чист случај образовања територијалне аутономије“.

Коначно, Минић је подсетио да је Треће заседање АВНОЈ-а 7-10. августа 1945. године одобрило прикључење Аутономне Покрајине Војводине Србији, „решавајући на тај начин једно од питања територијалног разграничења између народних република и отклањајући тако, као и у свим другим питањима, сваку могућност евентуалних територијалних спорова између појединих република“. Следствено томе, сматрао је Минић, када је 1946. године доношен Савезни устав, већ су постојале у Народној Републици Србији две аутономне јединице, АП Војводина и АКМО. „Устав ФНРЈ је могао само регистровати и ове политичке и правне чињенице у политичкој организацији једне од федералних јединица, федералне јединице Србије“, нагласио је Минић. У наставку опширне анализе Минић се враћао на идејне корене 
аутономних јединица, признајући да оне „спадају у ред оних категорија које смо преузели из Устава СССР од 1936. године“, али опомињући да разлоге њиховог стварања ипак „не треба тражити у простом пресађивању политичких облика совјетског уставног и државног система на наше домаће тле. Уствари, ради се о томе да смо за решење домаћих политичких потреба и проблема позајмили готове облике из совјетског државно-правног система““ Разлажући даље своју основну тезу, Минић је налазио тројаке разлоге за формирање аутономних јединица у НР Србији: особености привреде, живота и националног састава становништва. Историјски, географски и друге моменте Минић је сматрао од „неоспорно потпуно секундарног значаја“. Аргументујући своју тезу, Минић се позивао на „одговарајућа политичка и правна документа из године 1944., 1945., 1946. (између осталих заседања Антифашистичке скупштине народног ослобођења Србије и Народне скупштине Србије и др.) из којих се јасно види да је постојање више националности, национално шаренило, тј. посебан национални састав становништва у Војводини и Косовско-Метохијској Области, било један од мотива, разлога, основа за образовање територијалне аутономије, тј. самоуправе у Покрајини односно Области“.

Разматрајући даљи историјски развој аутономних јединица, Минић је подсетио да су у систему какав је постојао до 1953. године оне, као и републике уосталом, у пракси имале „и једино су могле имати више административни него политички карактер“. Међутим, у складу са увођењем система друштвеног самоуправљања, изменио се садржај аутономије, конкретно Уставним законом и Статутима аутономних јединица из 1953. године. По мишљењу Милоша Минића принцип територијалне аутономије тек тада је ступио на снагу и превазишао ниво администрације, а главно обележје покрајина „постаје самоуправа у свим пословима, у свим областима живота (у областима привреде, просвете, културе, социјалних и комуналних питања итд.), осим оних послова који су по уставним и другим правним нормама послови Федерације, народне републике, среза или општине“.

Сагледавајући развој аутономних јединица на тим основама после 1953. године Минићу је увидео потпуну „оправданост и неопходност примене принципа обласне аутономије у Војводини и Косову и Метохији“, истичући два главна разлога. Први - темпо привредног, културног и политичког развоја и други - унапређење међунационалних односа. Шире образлажући овај други резултат аутономије, Минић је тврдио да је њеном успоставом решено национално питање у Војводини, те да је према мањинама нестало „сваког националног угњетавања, сваких националних привилегија (на пример у погледу језика и др.), сваке националне неравноправности итд“, неизбежно то поредећи са међусобним сумњама, трвењима, шовинистичком мржњом „које познајемо из времена националног угњетавања у доба владавине великосрпског хегемонизма“. Благотворан учинак аутономије у побољшању међунационалних односа он је тумачио чињеницом „да је само становништво тих територија непосредно решавало сва та питања.“ 
Коначно, након обимног увода, Минић се дотакао и припрема новог Устава НРС и Статута аутономних јединица, наводећи да је нужно да се, сагледавајући искуства из петнаестогодишњег развоја аутономија, у будућем Уставу ,још разрађеније и тачније одређене основе за решавање проблема даљег развитка АПВ и АКМО“. Предвиђајући да ће у том погледу кључан бити „развој односа народна република - аутономна јединица и односа аутономна јединица - срез односно општина“, Минић је истакао два принципа као полазне тачке за одређивање обима и садржаја аутономије. Први, да се аутономна права не конституишу на рачун права општина и срезова и други, да се компетенције аутономних јединица конституишу из права и дужности које по Уставу и законима припадају народној републици, што због њихове ограничености од стране федерације није било изводљиво без тешкоћа.

Предочавајући резултате испитивања Комисије за законодавна и правна питања у Извршном већу НРС „у погледу праксе аутономних јединица и односа између њих и народне републике у свим областима политичке власти и управљања, у нормативној, извршној, управној“, Минић је издвојио два најмаркантније проблема. Наводно, прегледом службених листова аутономних јединица за 1959-60. годину констатовано је да су њихови представнички органи и извршна већа ,у протеклом периоду вршили у основи организациону функцију а да су веома мало користили уставна овлашћења за нормативно регулисање односа у напред цитираним односима“. Комисија се позвала на чињеницу да се највећи број аката донетих од органа аутономних јединица односио „на питања организације представничких органа, избора и разрешења, кадровска питања, оснивању или укидању самосталних установа“, док готово уопште нису уочени прописи којим се самостално регулишу поједина питања „од општег интереса за Покрајину односно Област“. Са друге стране, констатовано је да су надлежни органи у аутономним јединицама испољили велику активност у „остваривању извршних и управних функција, тј. функција делегираних од стране органа Републике, као и у погледу старања за спровођење политике развоја и привреде и јавних служби, за развој радничког и друштвеног самоуправљања и комуналног система на подручју аутономије“.

Изводећи закључке из цитираних извода, Минић је ценио да док извршни и управни органи Народне Републике скоро да нису имали посла на територији аутономних јединица „пошто су републички закони и уредбе те послове преносили извршним и управним органима аутономних јединица“, на другој страни су представничка тела аутономних јединица имала „врло мршав биланс, скоро да није било њихове значајније нормативне активности“, што је он видео као последицу чињенице „да Народна Република односно њена Народна скупштина није била много издашна у преношењу својих, иначе, као што смо већ видели, доста оскудних компетенција у законодавној, нормативној области на аутономне јединице“. Минић је стога упозоравао да се принцип аутономије „не исцрпљује самоуправом у извршној и управној области. 
Самоуправа у нормативној области рекао бих, чини неоспорно исто толико важан саставни део самоуправности, као и самоуправност у области извршној и управној“, те је препоручивао да у погледу нормативне области нови републички Устав треба да „одреди основ за праксу централних републичких тела и органа који би више него до сада уважавала и у законодавном и у нормативном раду опште потребне услове, тј. особености привреде и живота и националног састава становништва у АПВ и АКМО“.

Минић је предлагао да самим Уставом треба регулисати само принципе „који одређују статус и основне организације аутономних јединица, а препустити сва остала питања статутима аутономних јединица“. На крају, Минић је опомињао да савезно законодавство не треба да има никаквог удела „у расподељивању права, надлежности, овлашћења и одговорности између органа НРС и органа аутономних јединица и оно не може у то улазити а да не наруши принцип једнакости и равноправности народних република у погледу њихових права, компетенција, надлежности“. Аргументујући потребу уставних промена, Минић је напоменуо да долази до извесних сукоба као последица „извесне неодређености, недовољне прецизности, нејасних ставова у појединим питањима, у појединим пословима итд., из чега долази до тога да у одређеним случајевима настану различита схватања и спорови о томе шта спада или би требало да спада или не спада у надлежност аутономних јединица“. Стога је нови Устав Србије морао бити што прецизнији у утврђивању права, компетенције, надлежности и послова аутономних покрајина, што је био услов „не само за нестанак критика и спорова о којима је било речи него и за нормалну политичку борбу против појава и тенденција како бирократског централизма тако и бирократског партикуларизма“.

Минић је опширније елаборирао уочене централистичке, односно партикуларистичке појаве: „Са једних позиција критикује се претерано одвајање у пословима, надлежностима, правима аутономних јединица и тражи се јачи утицај и појачање права централних органа Народне Републике. У тој критици испољава се у исто време и помешано и реакција на, можда, донекле претерано или практицистички упрошћено и шаблонизирано преношење у извршној и управној области скоро свих компетенција на извршне и управне органе аутономних јединица, - са извесним очигледним тенденцијама које у крајњој линији нису ништа друго него тенденције и појаве републичког бирократског централизма. Са других позиција критикује се што се у још већем обиму не проширују компетенције органа аутономних јединица у разним областима. Кад се и ова критика подвргне анализи, може се раздвојити на два саставна дела: на нормалну реакцију против појава и тенденција републичког централизма у пословима које по природи ствари треба да врше органи аутономних јединица, који су, тако рећи, обласни, тј. најправилније се извршују у складу са особеностима аутономних јединица, те спадају у појам обласне аутономије; затим, на тенденцију у правцу слабљења веза између органа аутономних јединица и републичких органа, у правцу у 
крајњој линији бирократског партикуларистичког учауравања и затварања у себе, у границе своје области, ка положају неке самодовољности у односу према целини подручја НРС у погледу економском, културном, политичком, друштвеном, организационом итд“".

Минић се у свом спису опширно осврнуо на питање административне поделе Србије на срезове. Детаљно приказујући њен историјат од 1941. године надаље, сугерисао је да се приликом разматрања питања срезова у Војводини узме у обзир искуство јужне покрајине: „Ако би се срезови укинули, имали бисмо исту ситуацију као и у АКМО и све предности које тамо имамо, без обзира на постојећу разлику у величини Области и Покрајине (пошто величину саму за себе, без везе са свим условима, не можемо узимати као одлучујућу чињеницу у погледу опредељивања за једно или друго решење). Ако, обрнуто, срезови буду остали и надаље, у том случају, по свему судећи, мораће да се с великом пажњом испита да ли ће се моћи задржати и принцип да су и ти срезови исти као и сви други (уколико срезови буду остали у целој НРС), или ће се можда неки од досадашњих најважнијих послова срезова, које би требало решавати на исти начин за читаву АПВ (као што су на пр. питања привредног развоја и средстава за улагање у привредни развој и др. најкрупнија питања), пренети у надлежност покрајинских органа.“

Док је у Војводини сугерисао укидање срезова, Минић је за простор централне Србије предвидео њихово проширење и повећање надлежности. Како сукоби између општина и срезова нису били нестали (Минић је као забрињавајућу наводио појаву „среског централизма“), ваљало је новим уставним решењима променити статус срезова. У току дискусија по том питању закључено је да тенденција ка укрупњавању срезова води образовању територија „сличних по свим елементима већим областима“, што је неизоставно изискивало „ревизију улоге, функција, надлежности и организације среза, стварање у ствари једне територијалне организације друкчијег типа него што је срез у уобичајеном смислу речи. Треба обратити пажњу на важну чињеницу да се већ у то време јавља идеја о потреби за образовањем срезова или друкчијих самоуправних политичких јединица на ширим територијама. Ова идеја је настала на основи основних тенденција у развоју среза.“

Како је Минић увиђао, процес развоја среза у Србији, који је „уклањао старе границе срезова и водио формирању ширих области на основи колико-толико посебних услова привреде и живота становништва, географско-економских, саобраћајних, културних и др. особености“"није био доведен до краја. По његовом мишљењу многи срезови су још увек били мали по територији, становништву и привредној снази, а неки од њих „непотребно и неоправдано, са гледишта привредног и културног развоја раздвајају, деле, цепају извесне територије које имају мање или више сличне особености привреде и живота становништва“. Закључујући да срез „већ дуже време није више обична административна јединица централизованог државног 
механизма“ и да је преовладала концепција претварања среза у „политичку самоуправну јединицу шире категорије“, Минић је, позивајући се на марксистичка начела, заправо предлагао неку врсту регионализације Србије, која би се, слободни смо да закључимо, састојала од АП Војводине, АКМО, и неколико срезова (области) који би чинили територију уже Србије.

У склопу дискусија које су у партијским органим али и на ступцима штампе вођене почетком шездесетих година XX века, а поводом предстојеће уставне реформе, своју платформу имало је и руководство АП Војводине. Оно је предочено у виду неколико обимних докумената које су у пролеће 1961. године израдили стручњаци Завода за јавну управу АП Војводине. (Архив Војводине, фонд 198, кутија 140). Ради се о реферату др Будимира Дамјанова и Миливоја Ковачевића под насловом Ауйономна йокрајина Војводина (иоложај и ирава), Информачији о неким важним йийанима у вези са устиавном реформом и донощењем стиайуйа Ауйономне иоокрајине Војводине, Коменйарима о йройисима савезног̄ и рейубличког̄ устиава који регуулищу ирравни йоложај АП Војводине, те још неким елаборатима. Сви они су достављени највишим покрајинским функционерима - Стевану Дороњском, Гези Тиквицком, Шоти Палу, Душану Богданову, Петру Релићу, Ђури Јовановићу и Сави Малом.

Први од поменутих списа, под насловом Информација о неким важним йийанима у вези са усииавном реформом и донощењем сйайуйа Ауйономне йокрајине Војводине, садржи укратко изложене тезе које су опширно образложене у осталим документима, те их нећемо детаљније наводити. У Информацији се наглашава да „рад на припремању новог Устава захтева да се нека питање у вези са положајем и правима Аутономне покрајине Војводине размотре, како са становишта досадашњег друштвено-политичког и државног уређења, тако и из аспекта могућих решења у вези са положајем и правима АП Војводине у новом уставу“. Истиче се чињеница да су основни разлози за формирање аутономних јединица били „унутрашња национална сложеност и нарочито постојање националне мањине“, међутим, по речима састављача, увођењем друштвеног самоуправљања „суштина аутономије се знатно мења“. Аутономија је у том систему требало да добије обележја посебног облика самоуправљања радног народа, а аутономне јединице да постану друштвено-економске заједнице „што чини данас основну политичку снагу аутономије и перспективу њеног даљег развоја“. Одбацујући тврдње да би аутономија у новом Уставу, ако би садржала све предложене елементе, била противна јединству правног система Републике, и да би Србија била доведена у подређени положај у односу на остале републике које немају аутономне јединице, састављачи информације су констатовали да „,аутономија има свој основ једино у саставу Републике, па је та политичка и правна чињеница била и полазна тачка код разматрања будуће аутономије“. Из тога је изведен заључак да аутономија, коју је нови Устав требало да ближе дефинише, неће бити противна јединственом правном систему Републике, ,jер она представља 
такву надградњу која одговара развијености друштвено-економских односа и специфичностима Војводине и, речено уопште, одговара интензивном развитку комуналног система у Покрајини“, док је Република задржавала ингеренције и средства да обезбеди своје правно јединство.

Војвођански поглед на уставну реформу много је опширније образложен у реферату Ауйономна йокрајина Војводина (иоложај и иррава), који је био дело сарадника Завода за јавну управу АПВ, а разматран је и прихваћен од стране војвођанске Радне групе за проучавање уставних и статутарних питања 23. јуна 1961. године. Како су наглашавали сами његови творци, у реферату су дате „само основне идеје и елементи који и сами за себе могу послужити као основа за једну политичку дискусију“, а циљ му је био да „истакне неопходност аутономије Војводине као категорије општег уставног права“" Полазећи од тезе да Војводина није само уставно-правна или политичко-територијална формација, већ једна „животна целина“, те чињенице да је у току била промена карактера државе, коју је требало да санкционише нови уставни систем, аутори реферата су нагласили да ,аутономија треба да добије нови садржај и да се у вези са тим измене и односи између Покрајине и Републике“. Не спорећи да је Војводина саставни део Србије и да „сви они разлози који су за ово јединство постојали у време прикључења постоје и данас, у истој важности и дејству“, осетили су потребу да нагласе да Војводина као политичко-територијално подручје „није никаква вештачка творевина већ има своје историјске и правне основе, а створена је у току НОБ-а и живи у свести њених становника као посебна припадност".

Позивајући се на често истицану тезу да основ постојања АП Војводине лежи у постојању како националних мањина на њеној територији, тако и историјских разлога који су „довели и до одређених особености насталих на основи једног релативно вишег привредног и културног развитка“, писци реферата су изнели један опширан историјски увод. Полазећи од Велике сеобе Срба, па пратећи историјске догађаје до времена НОБ-а и револуције, покушали су да историографски поткрепе своје тврдње како Војводина никада није била интегрални део Србије и да уједињење са њом није извршено безусловно, те најзад „да је код Војвођана постојала и раније и сада постоји свест о својој посебности“. Поред општепознатих историјских чињеница везаних за борбу војвођанских Срба за своја права и своју Војводину, аутори су, тенденциозно или из незнања, изнели и више нетачних података. Тако на пример, исправно наводећи да је под утицајем Јаше Томића Велика народна скупштина у Новом Саду 1918. године донела одлуку да се Војводина без икаквих услова припоји Краљевини Србији, погрешно су тврдили да је иста та скупштина прихватила предлог Васе Стајића и његових истомишљеника да се Војводина прикључи Држави Словенаца, Хрвата и Срба са седиштем у Загребу.

Потпуно у духу оног времена, период прве југословенске државе осликан је мрачним бојама, са закључком да је процес политичке и културне инте- 
грације „који се природно развијао између Војводине и Србије насилно заустављен противнародном и хегемонистичком политиком великосрпске буржоазије између два рата“. Надовезујући се на историјски неспорну чињеницу да је Војводина у нову државу 1918. године ушла са привредном структуром у многим аспектима развијенијом од свих осталих покрајина сем Словеније, те да је услед неповољне пореске политике, светске економске кризе и губитка тржишта она прилично стагнирала до 1945. године, аутори су истакли да ни економска политика социјалистичке Југославије није погодовала војвођанској привреди. Стога су извели закључак да је због природе економских и друштвено-политичких проблема Војводине њих могуће решавати „само кроз и преко аутономног (у сваком погледу) статуса Војводине, у њој самој, путем њених органа, организација и установа“. Свакако, као кључни историјски чинилац у прилог покрајинске аутономије наведено је да је једна од парола НОБ-а 1941-1945. године била „идеја о војвођанској посебности и бољем положају Војводине у новој Југославији“.

У наставку су анализирани материјални основи војвођанске аутономије, од којих је на првом месту истакнуто плодно земљиште, а потом и резерве нафте и гаса, инфраструктура, као и водни токови и хидромелиорациони систем. У вези са тим, аутори су били мишљења да „већ због самог хидросистема би морала постојати нека аутономна управа“, наводећи пример самоуправе долине реке Тенеси у Америци. Није пропуштена прилика да се изнесу у то време често истицани подаци да је Војводина по националном дохотку била за $1,4 \%$ испод југословенског просека у земљи а за $6,8 \%$ изнад просека НР Србије, док је 1947. године војвођански доходак био за 26\% већи од југословенског просека, а за 21,7\% већи од просека НР Србије. Предочена је и чињеница да је у индустрији Војводине техничка опремљеност у том моменту била нижа за $33 \%$ од нивоа у југословенској индустрији и рударству, као и да су у периоду од 1957. до 1960. године инвестиције у Војводини износиле мање од половине југословенског просека.

По аутомима реферата, привредно заостајање Војводине могло се превазићи уставним променама. Требало је односе буџета аутономне јединице и Народне републике у финансирању друштвених потреба променити на тај начин што би се на аутономне јединице пренеле оне функције које је до тада задржавала Република, што је подразумевало и стварање одговарајуће материјалне основе за њихово финансирање. „Ово значи да би се и односи у расподели средстава буџета аутономне јединице и народне републике морали мењати у корист аутономне јединице“, предлагали су аутори, незадовољни тренутним односом у расподели буџетских средстава. На тапету је била и фондовска потрошња, а Ковачевић и Дамјанов су изнели мишљење да би средства намењена за њу у потпуности или већим делом требало да се уплаћују у фондове аутономних јединица, а не да их у највећој мери задржава Република, што је до тада био случај.

У одељку посвећеном разматрању позитивно-правног регулисања аутономија истиче се да су оне „категорија федерације, а не само специфичност 
једне од република“, те да посебну карактеристику њиховог правног положаја чине две уставне категорије које „у пракси нису нашле одговарајућу примену“. Као такве, наведене су улога у механизму контроле уставности закона, односно могућност приговора за заштиту аутономних права. Пишући о организацији и функционисању органа Покрајине аутори су приметили да „Народна скупштина АП Војводине скоро није користила право на самостално уређивање друштвених односа прописима (материјално-правни прописи) јер је донела свега два оваква прописа, и то Одлуку о забрани печења ракије од скробних материјала и Одлуку о коришћењу земљишта у грађевинске сврхе. Своја пак овлашћења за доношење допунских прописа уопште није користила, јер није донела ниједан такав пропис, а исто тако ни један пропис којим би се утврђивала општа начела за организацију и рад народних одбора. Исто тако пада у очи мали број препорука, којих је донето свега дванаест за осам година“. Разлози за такву праксу нису били прецизирани, али су проналажени у „правној, економској и политичкој сфери“.

Анализом делокруга рада војвођанског Извршног већа, констатовано је да је донет релативно мали број нормативних прописа „с обзиром на незнатан обим нормативне делатности Народне скупштине АП Војводине и изостајање одговарајућег овлашћења у законима или уредбама Савезног и Републичког извршног већа“. Закључено је да ће будуће компетенције Извршног већа зависити од ширине права Народне скупштине АПВ, те да се услед тога ово питање повезује са питањем овлашћења Народне скупштине. Предложено је да покрајинско Извршно веће убудуће врши „све оне послове које на подручју уже Србије врши Републичко извршно веће, сем оних који су задржани у искључивој надлежности Републичког извршног већа“. Коначно, полемишући са водећим српским правним теоретичарем Јованом Ђорђевићем око карактера и садржаја аутономије, писци реферата су оспоравали његов став да би аутономија требало да буде ближа локалној него републичкој самоуправи. У прилог својој тези да Војводина има посебно место и улогу у односима федерације, аутори су навели сложене задатке АП Војводине у „стварању братства и јединства међу разним националностима и у изградњи - први пут у свету - социјалистичких друштвених односа у пољопривреди“", те да је по територијалном обиму и броју становника, као и по економској снази, Војводина испред већине република.

Након темељне анализе историјата и тренутног положаја војвођанске аутономије, представљено је десет елемената које би војвођанско руководство морало узети у обзир у току одређивања новог садржаја аутономије, а који би требало да буду правно формулисани у савезном и републичком Уставу и детаљно разрађени у новом Статуту АП Војводине. Набројане су: посебности које представљају основе за постојање аутономије; територија и територијални интегритет; право на сопствено политичко представништво и на политичко представништво у Републици и Федерацији; право на самоорганизацију - укључујући овде све врсте организовања (територијалног - кому- 
не и срезови, разна удружења, коморе, установе итд.); правно регулисање сопственим прописима одређених друштвених односа, изузимајући само оне који су искључиво задржани за Федерацију и Републику; право располагања својим материјалним средствима, право на своју материјалну основу, тј. фондове и друга средства; право одређивања и утврђивања свог привредног, културног и другог развоја у оквирима и границама шире заједнице републике, и утврђивање тих оквира; право успостављања одређених односа непосредно са Федерацијом или другим републикама, а не само преко Републике; право на организовање сопственог правосуђа у складу са начелима утврђеним у Савезном уставу; решавање евентуалних спорова да буде у рукама Федерације.

У наставку су дати конкретни предлози за ново формулисање спорних одредби. Што се тиче утврђивања садржине и права Аутономне покрајине Војводине, сугерисано је да регулисање тог питања мора да нађе место у будућем Савезном уставу, који би требало да дефинише аутономију и одреди њен садржај и обим, ,чиме би били утврђени принципи и основе које би даље разрадио устав НР Србије“. Нови савезни Устав би морао и да штити аутономна права, што је до тада било поверено републичком Уставу. Тиме би се, по мишљењу аутора, превазишао проблем у реализацији, али и заштити аутономних права, која је до тада вршена на начин да је републичка Народна скупштина решавала о приговорима покрајинске скупштине против аката републичког Извршног већа којима су та права била повређена.

У намери да се знатно прошири нормативна активност покрајинских органа, предложена је промена начина правног регулисања њихових овлашћења. Будући да је по актуелном Уставу Покрајина вршила своја овлашћења на рачун овлашћења Републике, закључивали су у Заводу за јавну управу, покрајинска нормативна делатност је зависила од тога да ли ће републички органи нешто регулисати својим прописима или не. Како су републички органи изузетно развили своју делатност у том правцу, то је довело до фактичке ситуације да покрајинским органима није остало скоро ништа што није било регулисано републичким прописима. Стога је, предлагали су аутори реферата, односе у нормативној делатности требало утврдити у савезном Уставу начелно, а у републичком Уставу конкретно „и то тако што би се утврдило у којим материјама припада републици право искључивог законодавства, а у свим осталим материјама би република могла да доноси само опште законе, којима би се утврђивала општа начела“. Неопходно је било, сматрали су, да се утврди таква законодавна процедура која би подразумевала претходно мишљење Народне скупштине АПВ код доношења закона који се односе на питања од општег интереса за Републику, а у којима се изражавају специфични интереси Покрајине. На пример, код евентуалних територијалних промена одредило би се да се од Покрајине тражи претходна сагласност за те промене на њеном подручју, а ,могла би се пронаћи и одговарајућа политичко-правна форма за законодавну иницијативу народних 
посланика у Републичкој народној скупштини који су изабрани на територији Војводине“.

Дотичући се и израде новог Статута АП Војводине, предложено је да он добије другачији карактер: уместо акта о организацији и надлежности Покрајинске Народне скупштине, какав је био постојећи, требало је изменити његову суштину и садржину како би постао акт уставно-правног карактера. Право Аутономне покрајине Војводине на самоорганизацију по тада важећим уставним прописима било је тако регулисано да је Статут АП Војводине у ствари представљао копију одговарајућег дела Устава НР Србије. Предложено је да се у Уставу НР Србије утврде само основи организације и међусобни односи између републике и аутономне јединице, а да се ова питања конкретно регулишу кроз покрајински Статут. Поменуто је и врло важно питање оснивања заједница привредних организација, за шта је начела требало да утврди савезни Устав, ,јер се овде ради не о праву републике или Покрајине, него о праву самоуправних организација“. Тиме би се створила слобода заједницама привредних и других организација и установа са подручја АП Војводине да саме одлучују о томе да ли ће да улазе у састав заједница које се стварају у Републици.

Учешће Војводине у вршењу власти Федерације требало је да остане на нивоу покрајинске делегације (од шест посланика) у Савезном већу савезне Народне скупштине. Предвиђено је да на постојећем нивоу остане и улога покрајине у заштити права националних мањина, али би јој, сматрало се, било неопходно доделити додатна материјална средства и проширити ингеренције у вези са нормативном делатности по питањима мањина. Писци елабората су мислили како би било врло корисно „када би покрајински органи могли доносити допунске прописе непосредно на основу савезних прописа“. У вези са организацијом судства у покрајини, требало је задржати постојећи ниво судске аутономије, која се огледала пре свега у постојању Врховног суда Војводине, који је у свим пословима и надлежностима био изједначен са републичким Врховним судовима и директно везан за савезни Врховни суд. Поред тога, у вези са најавом да ће се образовати савезни Уставни суд, а потом и републички Уставни судови, закључено је да би један такав правосудни орган морала добити и Војводина.

Наредне странице реферата биле су посвећене области привреде, са напоменом да „кључно питање у одређивању суштине аутономије је одређивање материјалне базе“. Предложено је да се у економској сфери прошире компетенције покрајинских органа преузимањем одређених послова Републике „но не на рачун комуне које остају носилац привредног развоја“. Највише простора посвећено је питању инвестиционих фондова, позивајући се на чињеницу да покрајински фондови нису обезбеђивали довољно средстава, а расподела средстава из републичких фондова је била у домену републичких органа. Предложено је да се таква ситуација превазиђе опет посредством Федерације, која би „својим инструментима одређивала учешће 
Покрајине у републичким фондовима, као минимално учешће и тиме одредила заштитну границу материјалне основе аутономних права“. Тиме би, по мишљењу састављача реферата који смо укратко приказали, била обезбеђена материјална база аутономије Војводине.

У једном опширном елаборату, датираним са 18. јуном 1961. године, извршена је упоредна анализа одредби свих уставних аката социјалистичке Југославије и Србије које су се односиле на аутономију Војводине и дати су образложени предлози њихових промена. Овом приликом ћемо изложити само најважније примедбе. Тако је у вези са чланом 4., ставом 3. Уставног закона ФНРЈ од 13. јануара 1953. године, који је начелно укључивао Народну скупштину у систем нормативног регулисања самоуправљања, приговорено да се ради о одредби декларативног карактера. Та примедба је образложена чињеницом да је Република у својој надлежности задржала практично сва права, као и да својим прописима регулише и „она питања која су специфична за Војводину“. Стога је закључено да је дужност Републике да обезбеђује и штити аутономна права Покрајине „чиста декларација“, те да би у новом уставном систему требало аутономним јединицама утврдити и обезбедити аутономна права „тако да их Република не би могла сужавати него само проширити њихов круг“"

У вези са чланом 27. савезног Устава, који је прописивао број народних посланика републичких већа, односно Покрајинског и Обласног већа за Савезно веће Савезне скупштине, изражена је нада да ће се у новом Уставу изједначити број представника аутономних јединица са бројем представника република ,јер ови представници не представљају број становника република односно аутономних јединица па нема ни разлога да њихов број буде различит“. Освртом на члан 82., који је садржао опште одредбе о избору чланова Савезног извршног већа, покушано је да се избори загарантовано учешће представника аутономних јединица међу члановима СИВ-а, што су већ имале све републике. Аутономне јединице су до тада могле бити заступљене преко НР Србије, али је то зависило од њиховог политичког утицаја, па је сматрано да је „свакако повољније“ да се њихово учешће у СИВ-у обезбеди уставно-правно. Доцније разматрајући члан 107., који је садржао начелне одредбе о републичким Извршним већима, предложена је солуција да се савезним Уставом гарантује избор представника аутономија у републичко Извршно веће.

На самом крају елабората о Савезном уставу, након анализе његових чланова 113. и 114., покушано је да се превазиђе ситуација да Федерација само осигурава самоуправна права Покрајине, а да та права утврђује Република у своме Уставу. То је, по мишљењу састављача елабората, омогућавало Републици да највећи део права задржи за себе и да она буде „коначни арбитар“ за права Покрајине. Тај проблем би био решен тиме што би у савезном Уставу био одређен минимум аутономних права „који би Република могла само повећати а никако смањити“. У вези са тим, спорна је била и одредба 
савезног Устава о карактеру Статута аутономних јединица, који су били представљени као акти о организацији и надлежности органа власти аутономних јединица, а не као акти који би имали карактер „устава“ аутономне јединице. Стога је закључено да би било од „посебног интереса за Покрајину“ да у новом савезном Уставу покрајинском Статуту буде прописан већи значај.

У наставку је уследио осврт на републички Устав из 1947. године, односно Уставни закон из 1953. године. Анализирајући члан 13. Устава НР Србије, који је утврдио принцип „да се Уставном НР Србије обезбеђују аутономна права АП Војводине и АКМО, у сагласности са Савезним уставом“, сугерисано је да обезбеђење аутономних права Покрајине не буде само питање односа Републике и аутономних јединица, него да то питање добије што ширу потврду у савезном Уставу ,јер је принцип аутономије у суштини повезан с принципом федерализма“. То је, по мишљењу аутора, омогућавало Републици да готово сва права задржи у својој надлежности, што је могло бити превазиђено тиме што би принцип о аутономним правима био не само прокламован, него и регулисан Савезним уставом. Исти проблематичан принцип је био садржан и у Уставном закону НР Србије, који је у наставку анализиран.

Бавећи се чланом 3., ставом 3. Уставног закона, који је обезбеђивао право војвођанској скупштини да својим нормативним актима регулише самоуправљање у Покрајини, у сагласности са општим друштвеним интересима израженим у нормативним актима представничких тела Федерације односно Републике, аутори су прокоментарисали да та одредба нема стварну садржину, будући да је Народна скупштина АПВ имала незнатна овлашћења у поређењу са републичким органима власти. Зато је поновљено да је „од посебног интереса за Војводину“ да се у новом Савезном уставу утврде основна права аутономних јединица у погледу развијања друштвеног самоуправљања „тако да будући Устав НР Србије не може та права изменити нити ограничити на штету аутономних јединица“.

Замерке на члан 9. Уставног закона, који је утврђивао права и дужности републичких органа, ишле су на рачун сувише широких овлашћења републичких власти у регулисању друштвених односа, односно недовољних ингеренција покрајинских органа у том погледу. Због тога је у новом уставном систему, каже се у тексту, било потребно прецизно утврдити основна права аутономних јединица, како не би долазило до колизије овлашћења Републике и аутономија. У случају евентуалних спорова требало је створити могућност решења пред савезним органима. Члан 15., који је одређивао права и дужности органа власти аутономних јединица, био је споран у погледу непостојања овлашћења покрајинских власти да регулишу битна питања од општег интереса за Покрајину, „него су им само одређени послови које врше у спровођењу савезних и републичких прописа“. Домет таквих аката додатно је ограничавала чињеница да је крајње мерило законитости Статута 
аутономних јединица био републички Устав, те је новим уставним системом требало обезбедити органима власти аутономних јединица да на своме подручју стварно воде политику „у горе наведеним областима друштвеног живота“, а не да буду вршиоци управних послова заједно са републичким органима управе.

У блиској вези са тим биле су и одредбе члана 16., које су прописивале да у случају размимоилажења прописа аутономне јединице и републичког закона има да се примењује републички закон. Аутономне јединице су одраније имале право приговора за заштиту својих права, али је спорна била инстанца којој су се обраћали - републичка Народна скупштина. Ту улогу je, према предлогу састављача елабората, имала да преузме нека савезна установа, нпр. Уставни суд. Члан 24., који је садржавао одредбе о искључивој надлежности Народне скупштине НР Србије, између осталог давао јој је овлашћење да решава о приговорима представничког тела аутономних јединица за заштиту аутономних права против аката Републичког извршног већа, као и о приговорима народних одбора за заштиту самоуправних права против аката представничког тела аутономне јединице, али и да одлучује о промени граница између НР Србије и других република уз потврду савезне Народне скупштине. Као проблем у тим одредбама наведен је подређен положај скупштина аутономних јединица, које су замишљене као самосталније. За писце елабората је посебно забрињавајућа била могућност да се представничка тела аутономних јединица заобиђу у случају одлучивања о промени граница НР Србије, те је било неопходно да се обезбеди утицај покрајинске Народне скупштине „тако што би ово тело било супотписник републичких закона који би регулисали ово питање када се тиче територије Покрајине“.

Споран је био и члан 26., којим је Република ,резервисала за себе искључиво право да доноси прописе којима се уређују питања од општег интере$\mathrm{ca}$, а у којима су интереси Покрајине нарочито изражени, као и питања која су од посебног интереса за Војводину и која би, с обзиром на специфичност Војводине, требало да утврђују покрајински органи власти самостално“. Набројана су питања: организације власти и јавних служби, поделе територија Покрајине на општине и срезове, планског управљања привредом, привредних организација, буџета, универзитета и високих школа, стручних и других школа, народног здравља и др. Такође, Република је фактички имала већи утицај на развој срезова и општина на простору аутономних јединица, него оне саме, па је предложено је да се новим уставним системом Покрајини обезебеде већа права у том погледу.

Члан 71. омогућавао је републичком Извршном већу да врши надзор у погледу законитости рада покрајинске Народне скупштине и Извршног већа, чиме се, по мишљењу састављача елабората, крњио „принцип аутономије и политички утицај највишег представничког тела у Покрајини“. Предложено је да се надзорна права Републике над радом органа власти аутономних јединица пребаце у компетенцију савезних органа, као и ингеренције 
Републичког извршног већа у погледу приговора за заштиту самоуправних права од стране Извршних већа аутономних јединица. Чланом 72. била су конкретно утврђена овлашћења Републичког извршног већа у вршењу права надзора у погледу законитости рада представничких тела аутономних јединица и њихових Извршних већа, укључујући и право да им поништи или укине акте, ако процени да су незаконити или да вређају општи интеpec. То се такође морало ставити у надлежност федерације, предлагали су аутори елабората.

Члан 105. Уставног закона одређивао је делокруг питања која су представничка тела аутономних јединица могла регулисати својим прописима, као и начин решавања проблема у случају размимоилажења тих прописа са републичким законима. Међутим, сматрано је да је постојећи делокруг сужен и да би га требало проширити, а тиме и превазићи постојећу одредбу да се у случају размимоилажења покрајинских прописа и републичког закона примењује непосредно републички закон. Чланом 106., који је између осталог прописивао да Народна скупштина АП Војводине може продужити свој мандат у случају ванредних прилика, уз сагласност Републичке Народне скупштине, замерено је што покрајинску Скупштину третира као „тело нижег ранга“, што је било неспојиво с начелом да је Народна скупштина АПВ највиши орган власти на своме подручју. Исти случај је био и са покрајинским Извршним већем, чији је делокруг ингеренција, прецизно одређен чланом 114., задовољавао састављаче елабората. Међутим, они су проблем налазили у суштинском политичком значају тог тела, који је зависио „од решења статуса и политичког утицаја Покрајинске Народне скупштине, а у крајњој линији друштвеног и правног положаја Покрајине у новом уставном систему“.

Резиме: Шездесете године двадесетог века у Југославији, на унутрашњем плану, биле су обележене уставном реформом, која је имала за циљ да постави нове односе између република и савезне државе, односно аутономних покрајина и Републике Србије. Као што је и реформа савезног устава протицала у знаку судара две концепције (које су персонификовали Едвард Кардељ и Александар Ранковић), тако је и будући положај АП Војводине изазвао стручну полемику истакнутог српског функционера Милоша Минића и војвођанских правних стручњака, окупљених у Заводу за јавну управу АП Војводине. Минићев Прилог̄ дискусији о новом устиаву (у скраћеном издању у складу са расположивим просторим у дневним новинама, а можда и политичким потребама) објављен је половином октобра 1961. године у Борби, у четири наставка. Сам аутор је свој допринос правдао потребом да изнесе своје мишљење у склопу текућих припрема уставних нацрта. На самом почетку Милош Минић је опширно анализирао марксистичко-лењинистичка теоријска гледишта о принципима политичког уређења, између осталог и о аутономији и централизму. Други део Прилог̄ $a$ бави се југословенским иску- 
ством федерализма, са посебним освртом на односе савезне државе и њених федералних јединица. Трећи наставак у потпуности је посвећен развоју срезова, док је последњи део Минићевог списа, по његовим речима „веома кратак извод из опширније анализе извесних основних политичких и правних питања развоја аутономних покрајина“. Да војвођанско руководство ипак није било затечено Минићевим пројектом, него да је месецима пре његовог обнародовања имала изграђен поглед на будући статус Покрајине, види се из документације Завода за јавну управу АП Војводине, који је своје мишљење о предстојећим уставним променама предочио још у пролеће (мај-јун) 1961. године, у виду неколико обимних списа. Ради се о реферату др Будимира Дамјанова и Миливоја Ковачевића под насловом Аутиономна йокрајина Војводина (йоложај и йрава), Информацији о неким важним йийањима у вези са устиавном реформом и дономењем стиайуйа Аутиономне иокрајине Војводине, Коменйарима о ироииисима савезног и рейубличког̄ устйва који регуулищу ирравни йоложај АП Војводине, те још неким елаборатима.

\section{ИЗВОРИ}

Архив Војводине, Нови Сад, фонд 198. (Покрајинско извршно веће)

\section{ЛИТЕРАТУРА}

Бјелица, С. (2011). Сукоб око аутономије Војводине 1961-1962. Годишњак Филозофског факултета у Новом Саду, 36/1, 19-29.

Димић, Љ. (2001). Историја српске државности-Србија у Југославији. Нови Сад: Православна реч.

Кончар, Р., и Боаров, Д. (2011). Стеван Дороњски - одбрана аутономије Војводине. Нови Сад: Агенција МИР.

Минић, М. (18. окт. 1961). Прилог дискусији о новом уставу. Борба, стр. 4.

Ницовић, Јанко (2007). Уставни развој Србије 1804-2006, Београд: Sezam medico.

Петрановић, Б., и Зечевић, М. (1987). Југословенски федерализам - идеје и стварност.

Београд: Просвета.

Поповић, Д. (2006). Летопис о Влаовићима. Нови Сад: Агенција МИР.

Слободан Бјелица

\section{TWO CONCEPTIONS OF THE STANDING OF VOJVODINA DURING THE CONSTITUTIONAL REFORMS OF THE 1960S}

\section{SUMMARY}

In Yugoslavia in the 1960s there were marked constitutional reforms in the internal plan, the goal of which was to establish new relations between the republics and the federal state and, in particular, between the autonomous provinces and the Republic of Serbia. Just as the reforms of 
the federal constitution took place as a sign of a conflict between two conceps (which were personified by Evard Kardelj and Aleksandar Ranković), so did the future standing of the AP (Autonomous Province) of Vojvodina provoke the expert polemics of the prominent Serbian official, Miloš Milić and the Vojvodinian legal experts assembled in the Office of Public Administration of the AP Vojvodina.

Milićs Supplement to the Discussions about the New Constitution was published in the middle of October, 1960 in the newspaper Borba in four installments, in an abridged format according to the available space in daily newspapers, as well as according to perhaps political necessity. The author himself justified his contribution by the need to assert his opinion within the ongoing preparations for the constitutional bill. At the very beginning, Miloš Minić extensively analyzed the Marxist-Leninist theoretical view of the principles of political organization, as well as of autonomy and centralization. The second part of the Supplement dealt with the Yugoslav experience with federalism with particular reference to relations between the federal state and its federal units. The third installment was completely devoted to the development of counties, while the final part of Minić's document was, according to him, "a very short summary of a detailed analysis of certain basic legal and political questions concerning the development of autonomous provinces."

In fact, the Vojvodinian leadership had not been caught off-guard by Minić's project. Rather, a few months before it was proclaimed to the people, it had a conscious view of the Province's future status. This was evident in documents from the Office of Public Administration of the AP Vojvodina, which had already presented its opinion of the forthcoming constitutional changes in the spring (May-June) of 1961 in the form of a few comprehensive documents. These included a report by Dr. Budimir Damjanov and Milivoj Kovačević entitled The Autonomous Province of Vojvodina, Commentaries on Regulations on the Federal and Repubic Constitutions which Regulate the Legal Standing of AP Vojvodina, and some further elaborations.

Key words: Autonomy, Vojvodina, Serbija, Constitution 